\title{
Evaluation of Energy Aspects of Apple Drying in the Hot-Air and Infrared Dryers
}

\author{
${ }^{1}$ Seyed Hashem Samadi and ${ }^{2}$ Issa Loghmanieh \\ ${ }^{1}$ Department of Agricultural Machinery Engineering, \\ Agricultural Faculty, TarbiatModaresUniversity, Tehran, Iran \\ ${ }^{2}$ Department of Mechanization of Agricultural Machinery, \\ Agricultural Faculty, Islamic Azad University Science and Research Branch, Tehran, Iran
}

Received 2013-08-19; Revised 2013-08-24; Accepted 2013-08-26

\begin{abstract}
Drying is an energy-intensive process. In general, heating and evaporation require large quantities of energy. This study has been conducted to evaluate analysis for dying apple slices in two drying systems including hot-air convection and infrared drying. The apple samples were dried at temperatures of 90, 120 and $150^{\circ} \mathrm{C}$ and radiation intensity of $0.22,0.31$ and $0.49 \mathrm{~W} / \mathrm{cm}^{2}$ in the hot-air and infrared dryer, respectively. The results showed that the minimum energy consumed for drying apple slices in infrared dryer was $1 \mathrm{~kW} \mathrm{~h}$ while minimum energy consumption in hot air dryer was $7.02 \mathrm{~kW} \mathrm{~h}$. Also, the specific energy consumption in IR dying was about $82-86 \%$ shorter than that of hot-air drying. The value of SEC of apple under IR and hot air drying was ranged from 110.35 to $71.78 \mathrm{kWh} / \mathrm{kg}_{\text {water }}$ and 635.53 to $501.15 \mathrm{kWh} / \mathrm{Kg}_{\text {water }}$, respectively. The calculated value of moisture diffusivity varied from $3.499 \times 10-7-4.746 \times 10-7 \mathrm{~m}^{2} / \mathrm{sec}$ and $3.671 \times 10-7-5.101 \times 10-7 \mathrm{~m}^{2} / \mathrm{sec}$ and the value of energy activation were found to be 140.1 and $94.62 \mathrm{~kJ} \mathrm{moL}^{-1}$ for IR and hot air drying, respectively. Therefore, one way to improve drying operations is to use infrared energy.
\end{abstract}

Keywords: Drying, Energy Consumption, Infrared, Hot Air, Moisture Diffusivity

\section{INTRODUCTION}

Apple from the pomaceous fruit of the apple tree, species Malusdomestica in the rose family (Rosaceae), is one of the most important horticultural crops, native to cold-temperate zones that are cultivated all over the world in many countries (Forsline et al., 2002). Apple is one of the most important horticultural crops in many countriese specially Iran. More than 1660000 tons of apples are produced in Iran (FAOSTAT, 2012).

A quality loss of fruits was happen between harvest and consumption. unsuitable preservation and storage methods cause losses of fruits and vegetables which range from 10 to $30 \%$ (Purkayastha et al., 2013). Various methods are used for the storage of agricultural materials after harvesting. Dryingis an important dehydration technique in food industry and the oldest method of food preservation. Drying process reduces the water activity of products, reduction of microbiological activity and minimizes physical and chemical changes of products during Storage. Appropriate methods of drying are reduced a lot of damagein the later stages of post harvesting of the product (Doymaz and Ismail, 2011; VijayaVenkataRaman et al., 2012). In the developing countries, still drying of agricultural products using traditional methods (sun drying) is done. This method has the advantages of simplicity and the low capital, but requiring the long drying times, is extremely weather dependent, possibility of microbial activity during drying and undesirable quality of the dried product its disadvantages (Kamble et al., 2011).

In recent years, industrial dryers have been replaced the traditional methods for drying agricultural products. In industrial dryers, drying condition more controlled, the drying time is shorter and final product quality

Corresponding Author: Seyed Hashem Samadi, Department of Agricultural Machinery Engineering, Agricultural Faculty, TarbiatModares University, Tehran, Iran 
improved. As drying is one of the most energy intensive processes and dryers are expensive pieces of equipment, drying must be carried out as economically as possible. Various drying methods have been developed and useto dry different food produce (Van 't Land, 2011).

Hot air convection drying is one of the oldest techniques and the most common used techniques of drying. Over $85 \%$ of industrial dryers are of convection drying using hot air systems. In this dryer, hot air. The heat required for evaporation of the moisture is provided by the hot air. Convective drying is accomplished heated air is brought into contact with the wet material to be dried to facilitate heat and mass transfer. The basic concepts, various methods of drying and different types of hot air dryers excited (Zlatanović et al., 2013)

One of the increasingly popular, but not yet common, methods of supplying heat to the product for drying operations is Infrared (IR) radiation. Infrared energy can be generated by type of electromagnetic radiation. The wavelengths used are in the range 1 to $6 \mu \mathrm{m}$. IR radiationscan be generated in one of two ways: electrically or burning gas that heats a ceramic plate. The IR radiation received by a body is absorbed, reflected, or transmitted. The part of the absorbed energy is the only effective part for drying. The infrared radiation impinges and penetrates on the inner layer of materials without heating surrounding airand then is converted to sensible heat. During drying decreases the absorptivity and increases reflectivity of the dried material because of decrease water content in it (Balbay et al., 2012; Darvishi et al., 2013; Ponkham et al., 2012)

Several recent researchers have been studied in drying of agriculture products with infrared energy such as: Vegetables (Hebbar et al., 2004), paddy (Meeso et al., 2004), apple slice (Nowak and Lewicki, 2004), onion slices (Pathare and Sharma, 2006; Sharma et al., 2005), sweet potato (Lin et al., 2005), peach (Wang and Sheng, 2006), banana slices (Nimmol et al., 2007), blueberries (Shi et al., 2008), grape (Celma et al., 2009), longan fruit (Nathakaranakule et al., 2010), rough rice (Khir et al., 2011), soybean (Niamnuy et al., 2012), carrot (Vishwanathan et al., 2013). However, there is no extensive and complete research on investigation of energy aspect in drying of apple using hot air and infrared drying.The study objectives include comparing the evaluation of energy and efficiency, drying kinetic and activation energy during drying of the apple slices using two drying methods including hot air and infrared drying.

\section{EXPERIMENTAL SECTION}

\subsection{Materials}

Apple slices were used to conduct the experiments. In this study samples were freshly provided from a local market of Tehran and were stored in a refrigerator at about $4 \pm 1{ }^{\circ} \mathrm{C}$ for the experiments. Applewas cut in $5 \mathrm{~mm}$ thick slices and about 18 gr of them was put on the dryer platform after preparing and adjusting the dryers. Initial moisture content of apple was determined by drying the apple in the oven at $105 \pm 1^{\circ} \mathrm{C}$ for $12 \mathrm{~h}$ (Shi et al., 2013). The experiments were performed in triplicate. The fresh samples were found to have a moisture content of about $82 \pm 0.5 \%$ w.b. (wet basis).

\subsection{Drying Apparatus}

\subsubsection{Hot Air Drying}

A laboratory scale electric hot air dryer was used for drying apple slice, which could be regulated to any desired drying air temperature and air velocity between 20 to $250^{\circ} \mathrm{C}$ and 0.2 to $3 \mathrm{~m} \mathrm{sec}^{-1}$ respectively, with high accuracy.The dryer consists of an electrical fan, an air flow velocity control system, an electric heater unit, drier air temperature control system, measurement sensors and drying chamber. The heating control unit included an electric heater and a fan placed inside a duct. Apple slices were placed in a dryer's tray which located in the center of the chamber.The samples were weighed during the drying process using a digital balance with 0.01 accuracy and 1500 g capacity (GF-600, A and D, Japan). The air velocity was kept at a constant value of $1 \pm 0.02 \mathrm{~m} \mathrm{sec}^{-1}$ that measured a anemometerwith the accuracy of $\pm 0.02 \mathrm{~m} \mathrm{sec}^{-1}$, (Anemometer, Lutron-YK, 80AM, Taiwan). Also temperature was measured by using $\mathrm{K}$ type thermocouple with the accuracy of $\pm 1^{\circ} \mathrm{C}$. The experiment was carried out for 90,120 and $150^{\circ} \mathrm{C}$ drying temperature.

\subsubsection{Infrared Drying (IR)}

In this study, transmit electromagnetic radiation that waselectrically generated, as drying equipment was used. This dryer consist mainly of two parts, an infrared radiation chamber and an air duct. The infrared chamber was placed above the air duct. Forsupplying infrared radiation were used infrared lamps (OSRAM Co., Ltd., Slovakia). Infrared radiation is emitted from the head gate to the product. For different radiation intensity on the product, distance of lamp from the product surface is changed. Also, this dryer has a suction centrifuge fan that air flow passed in parallel the bed product. Samples were located in the middle of the channel on the tray that was placed on a digital balance. Sample weight during 
drying was determined directly from digital balance (GF600 , A\&D, Japan) at about $30 \mathrm{sec}$ interval in each drying experimental. Radiation intensity and air velocity were adjusted using an intensity meter (IR intensity meter, OPHIR, USA) and anemometer (Anemometer, Lutron-YK, 80AM, Taiwan). The apple samples were dried in the infrared dryer at theradiation intensity of $0.22,0.31$ and $0.49 \mathrm{~W} / \mathrm{cm}^{2}$ in order to provide different sample temperatures 90,105 and $120^{\circ} \mathrm{C}$ and air velocity of $1 \pm 0.02 \mathrm{~m} \mathrm{sec}^{-1}$.

\subsection{Energy Utilization in Hot Air Drying}

In hot air drying, total energy utilizationof the drying process given to the drying and blowing air byelectric heater and fan, respectively.This value was calculated from Equation 1 (Motevali et al., 2011):

$$
\mathrm{E}_{\mathrm{u}}=\rho_{\mathrm{a}} \mathrm{AvC}_{\mathrm{pa}} \Delta \mathrm{T} . \mathrm{t}
$$

Where:

$\mathrm{E}_{\mathrm{u}}=$ The total energy utilization $(\mathrm{kWh})$

$\rho_{\mathrm{a}}=$ The air density in bulk temperature $\left(\mathrm{kg} / \mathrm{m}^{3}\right)$,

$\mathrm{A}=$ The cross sectional area of channel that samples are placed $\left(\mathrm{m}^{2}\right)$

$\mathrm{V}=$ The air velocity $(\mathrm{m} / \mathrm{sec})$

$\mathrm{C}_{\mathrm{pa}}=$ The specific heat of air in constant pressure $\left(\mathrm{kJ} / \mathrm{kg}{ }^{\circ} \mathrm{C}\right)$

$\Delta \mathrm{T}=\mathrm{A}$ temperature difference between air inlet and outlet of the dryer $\left({ }^{\circ} \mathrm{C}\right)$

$\mathrm{T}=$ The total drying time (h)

\subsection{Energy Utilization in Infrared Drying}

In the IR dryer, energy requirement is the sum of energy consumed by IR lamps to heating the samples and a fan that used for moving the heat air. In this study for supplying infrared radiation were used infrared lamps witch its power was $400 \mathrm{~W}$. The amount of power consumption by the fan used to move the drying air was calculated by digital Wattmeter (Lutron, DW-6060, Taiwan). Therefore, $E_{u}$ is the total energyutilization during drying with infrared drying is calculated using following Equation 2:

$$
\mathrm{E}_{\mathrm{u}}=\mathrm{E}_{\mathrm{u}, \mathrm{IR}}+\mathrm{E}_{\mathrm{u}, \mathrm{f}}
$$

\subsection{Specific Energy Consumption (SEC)}

The efficiency of energy consumption of the drying process was evaluated through the Specific Energy Consumption (SEC). The specific energy consumption which is a measure of the energy needed to evaporate a unit mass of water from the product. The energy consumed for drying a kilogram of apple slices is calculated using Equation (3) (Jindarat et al., 2011):

$\mathrm{SEC}=\frac{\mathrm{E}_{\mathrm{u}}}{\mathrm{m}_{\mathrm{w}}}$

Where:

$\mathrm{SEC}=$ The specific energy consumption $\left(\mathrm{kW} \cdot \mathrm{h} / \mathrm{kg}_{\mathrm{water}}\right)$

$\mathrm{m}_{\mathrm{w}}=$ The amount of water removed $(\mathrm{kg})$

Which is the difference between the initial and final weight of the process drying.

\subsection{Calculation of Activation Energy and Effective Diffusivity}

Effective moisture diffusivity is related to mass transfer, while air boundary heat and mass transfer coefficients are related to external heat and mass transfer, respectively. Fick's second diffusion equation has been widely used to describe the drying process for agricultural materials that is given as Equation 4 (Barati and Esfahani, 2011):

$\frac{\partial \mathrm{M}}{\partial \mathrm{t}}=\mathrm{D}_{\text {eff }} \frac{\partial^{2} \mathrm{M}}{\partial \mathrm{x}^{2}}$

The solution to the Fick's equation with the assumptions of moisture migration by diffusion only, negligible volume shrinkage, diffusion coefficients and constant temperature is solved Equation (5) (Ponkham et al., 2012):

$M R=\frac{M_{t}-M_{e}}{M_{o}-M_{e}}=\frac{8}{\pi^{2}} \sum_{n=1}^{\infty} \frac{1}{(2 n+1)^{2}} \exp \left(\frac{-(2 n+1)^{2} \pi^{2} D_{\text {eff }} t}{4 L^{2}}\right)$

Where:

MR = The moisture ratio (dimensionless)

$\mathrm{M}_{\mathrm{t}}, \mathrm{M}_{\mathrm{o}}$ and $\mathrm{M}_{\mathrm{e}}=$ Moisture content at any time, initial moisture content and equilibrium moisture content ( $\mathrm{kg}$ water $/ \mathrm{kg}$ dry mater ), respectively

$\mathrm{D}_{\text {eff }} \quad=$ The effective diffusivity $\left(\mathrm{m}^{2} / \mathrm{s}\right)$ and $\mathrm{L}$ is the half-thickness of samples

(m), $\mathrm{n} \quad=$ A positive integer

For long drying times Equation (5) can be simplified by using only the first term in the serieswithout much affecting the accuracy of the prediction (Samadi et al., 2013):

$\mathrm{MR}=\frac{8}{\pi^{2}} \exp \left[-\frac{\pi^{2} \mathrm{D}_{\text {eff }} \mathrm{t}}{4 \mathrm{~L}^{2}}\right]$ 
Equation 6 can be written in logarithmic form Equation 7:

$$
\operatorname{Ln}(M R)=\operatorname{Ln}\left(\frac{8}{\pi^{2}}\right)-\left(\frac{\pi^{2} D_{\text {eff }} t}{4 L^{2}}\right)
$$

The slope $(\mathrm{K})$ is calculated by plotting $\mathrm{Ln}(\mathrm{MR})$ versus time according to Equation (8):

$$
\mathrm{K}=\frac{\pi^{2} \mathrm{D}_{\text {eff }}}{4 \mathrm{~L}^{2}}
$$

The energy of activation was calculated by using an Arrhenius type equation (Dissa et al., 2011):

$$
D_{\text {eff }}=D_{0} \exp \left(-\frac{E_{a}}{R_{g} T}\right)
$$

Where:

$\mathrm{D}_{0}=$ The constant in Arrhenius equation $\left(\mathrm{m}^{2} / \mathrm{s}\right)$

$\mathrm{E}_{\mathrm{a}}=$ The activation energy $(\mathrm{kJ} / \mathrm{mol})$

$\mathrm{T}=$ Temperature of air $\left({ }^{\circ} \mathrm{C}\right)$ and

$\mathrm{R}=$ The universal gas constant $\left(8.3143 \mathrm{~kJ} \mathrm{moL}^{-1} \mathrm{~K}\right)$

Equation (9) can be rearranged into from by applying the logarithms as Equation 10:

$$
\operatorname{Ln}\left(D_{\text {eff }}\right)=\operatorname{Ln}\left(D_{0}\right)-\left(\frac{E_{a}}{R_{g} T}\right)
$$

\section{RESULTS AND DISCUSSION}

\subsection{Drying Kinetic}

Apple slices were dried from an initial moisture content of $85.3 \%$ to final moisture content of less than $12 \%$. The variation of Moisture Ratio (MR) with drying time at different drying condition for hot air and infrared drying are shown in Fig. 1 and 2, respectively. As seen from these figures, all curves have two steps. The moisture ratio rapidly reduces due to a reduction of the heat transfer resistance inside the material and increase of the mass transfer area. With increasing of the drying time, the hardened layer imposes a barrier against the dissipation of moisture across the product's surface and prolongs its departure from the product and so, moisture ratio slowly decreases (Bakal et al., 2011; Doymaz and Ismail, 2011). The effectiveness of increasing the drying air temperature in apple drying at thickness of $3 \mathrm{~mm}$ and constant air velocity $\left(1 \mathrm{~m} \mathrm{sec}^{-1}\right)$ in hot air drying shows that drying time decreased significantly with increasing the temperature drying (Fig. 1). The time to reach the moisture content of $12 \%$ (wet basis) was 90,81 and $71 \mathrm{~min}$ for temperature of 90,120 and $150^{\circ} \mathrm{C}$, respectively.
The effect of infrared power on the dehydration characteristics is shown in Fig. 2. Similar to hot air drying, the drying time decreased with increasing radiation intensity at the same moisture content and constant air velocity. Drying time at the radiation intensity of $0.22,0.31$ and $0.49 \mathrm{~W} / \mathrm{cm}^{2}$ for desired moisture content of 10 to $12 \%$ w.b were about 103,84 and $67 \mathrm{~min}$, respectively. These drying time values were used in estimating the specific energy consumption in the drying process. The results indicated that mass transfer was more rapid during the larger radiation intensity because more heat was generated within the sample. The temperature gradients between the air and the products in higher temperatures are higher than lower temperatures. Thus, in the higher temperature, increased energy of water molecules and decrease in relative moisture of sample and hence, drying time decreased (Doymaz, 2010; Motevali et al., 2010).

\subsection{Energy Analysis}

Figure 3 and 4 show the energy requirement in convection hot air and infrared drying of apple slices. It is seen that at constant air velocity, total energy requirement decreases with increasing air temperature andradiation intensity. In hot air drying by increasing the temperature of chamber drying, drying time has been reduced and thereof the energy consumption for drying was decreased. The value of total needed energy of apple under hot air drying was ranged from 7 to $8.9 \mathrm{kWh}$. Similar to hot air drying, the dehydration rate increased with increasing radiation intensity at the same moisture content. So, total needed energy was reduced (Fig. 4). The maximum and minimum value of total needed energy 1.54 and $1 \mathrm{kWh}$ was obtained at a radiation intensity of 0.22 and $0.49 \mathrm{~W} / \mathrm{cm}^{2}$, respectively.

Specific energy consumption of the drying process under different conditions was estimated, using Equation 3 and showed in Fig. 5 and 6. It is clearly seen from Fig. 5 that as temperature of drying air was increased from 90 to $150^{\circ} \mathrm{C}$, the specific energy consumption decreased from 635.53 to $501.15 \mathrm{kWh} / \mathrm{Kg}_{\text {water }}$ evaporated at an air velocity of $1.0 \mathrm{~m} \mathrm{sec}^{-1}$. The reason for this is that the dramatic reduction in the drying time with increase in air temperature. A similar trend was also observed in the specific energy consumption at IR drying. With increasing IR intensity, the thermal gradient inside and outside the product increases with temperature and moisture evaporation occurs faster. Therefore, drying time is reduced and the required specific energy decreases. The specific energy consumption reduced drastically during the IR drying as compared to the convective drying process. The value of SEC of apple under IR drying was ranged from 110.35 to $71.78 \mathrm{kWh} / \mathrm{kg}_{\text {water }}$. 


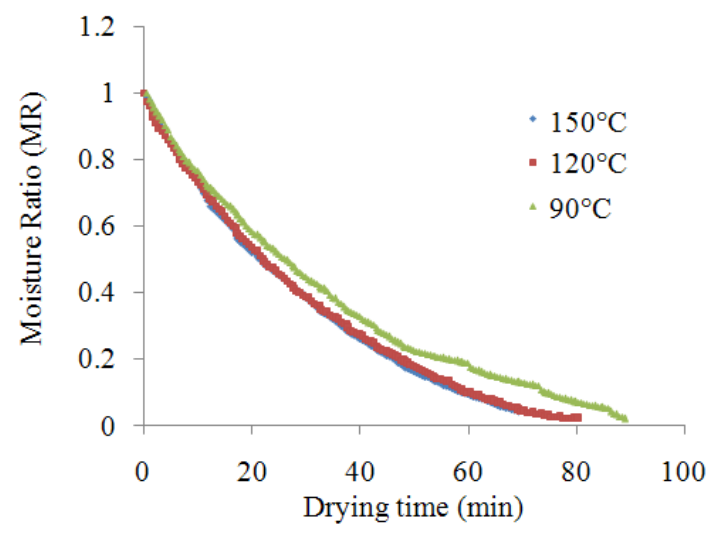

Fig. 1. Variation of moisture ratio with drying time for hot air drying at three different temperature, $\mathrm{v}=1 \mathrm{~m} / \mathrm{s}$ and Thickness $=5 \mathrm{~mm}$

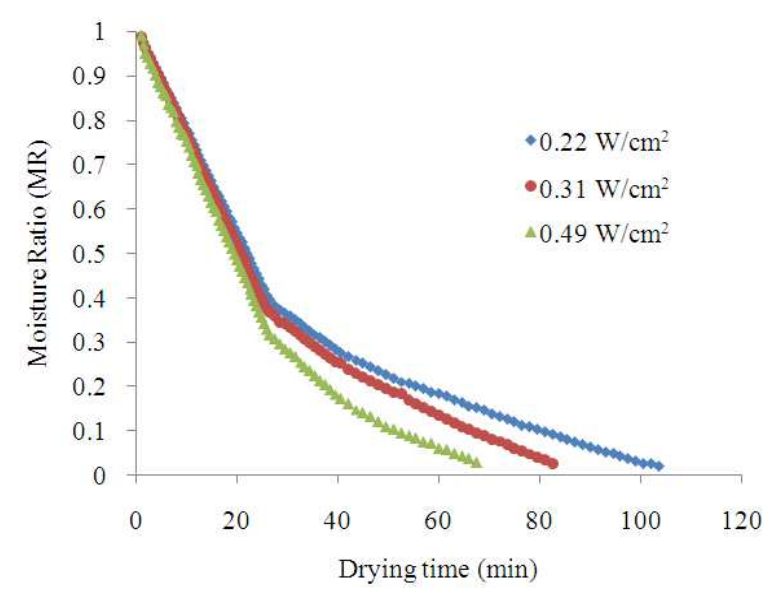

Fig. 2. Variation of moisture ratio with drying time for infrared drying at three radiation intensity, $\mathrm{v}=1 \mathrm{~m} \mathrm{sec}^{-1}$ and Thickness $=5 \mathrm{~mm}$

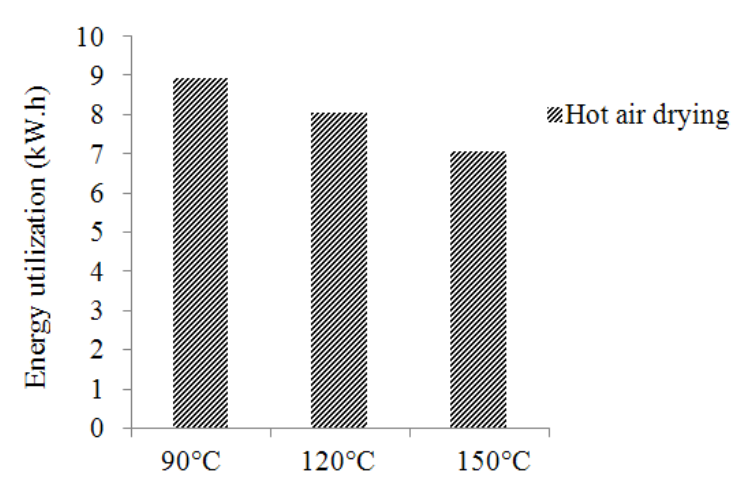

Fig. 3. Total energy requirement for hot air dryer at different temperatures

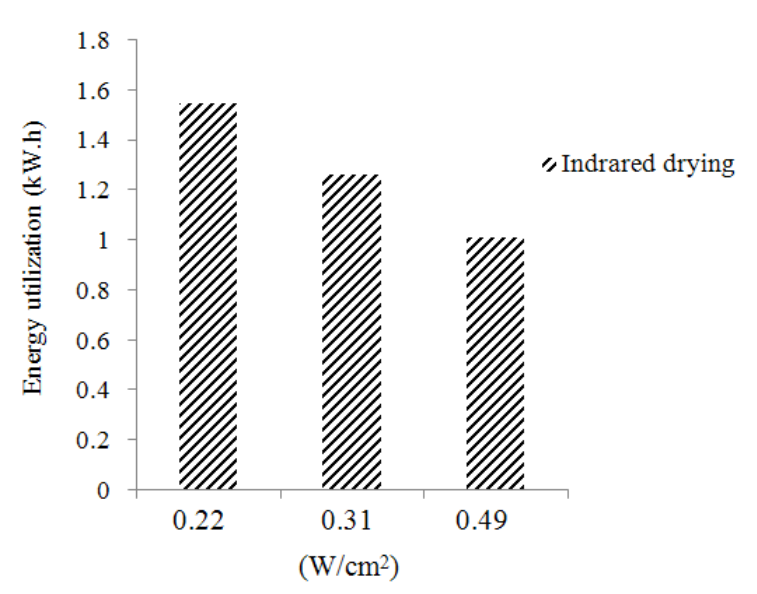

Fig. 4. Total energy requirement for infrared dryer at different radiation intensity

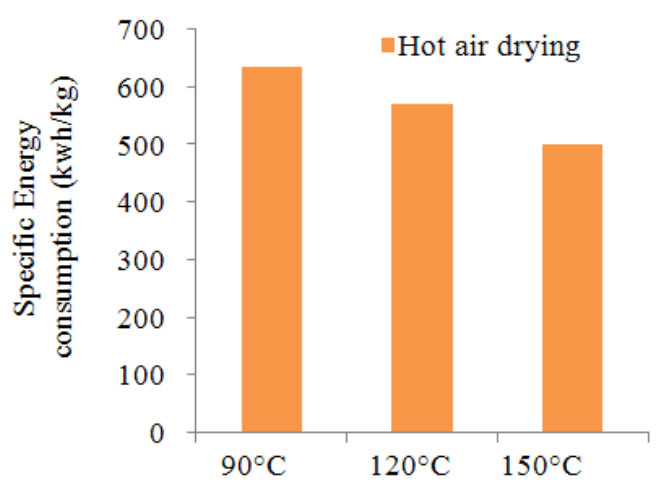

Fig. 5. Variation in specific energy consumption under hot air drying at air

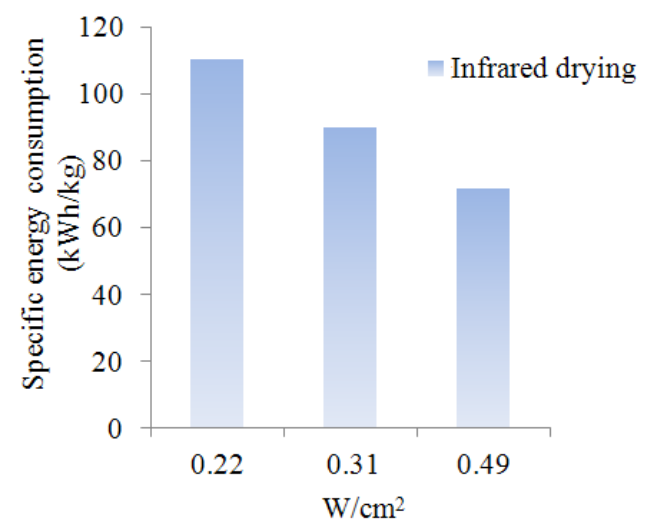

Fig. 6. Variation in specific energy consumption under IR drying at air velocity of $1.0 \mathrm{~m} \mathrm{sec}^{-1}$ 


\subsection{Activation Energy and Effective Diffusivity}

The determined values of effective moisture diffusivity $\left(\mathrm{D}_{\text {eff }}\right)$ for different hot air and IR drying are given in Table 1. The effective diffusivity was greatly influenced by the air temperature and radiation intensity. The values lie within the general range of $10^{-}$ ${ }^{6}-10^{-11} \mathrm{~m}^{2} / \mathrm{sec}$ for food materials. $5.612 \times 10^{-9}$ to $1.317 \times 10^{-8} \mathrm{~m}^{2} / \mathrm{s}$ for fluidized bed drying of apples (VijayaVenkataRaman et al., 2012), $4.606 \times 10^{-6}$ to $7.065 \times 10^{-6} \mathrm{~m}^{2} / \mathrm{sec}$ freeze-drying of apple cubes with far-infrared (Kahyaoglu et al., 2012), $3.17 \times 10^{-7}$ to $15.45 \times 10^{-7} \mathrm{~m}^{2} / \mathrm{sec}$ for thin-layer drying of apple slices in length of continuous band dryer (Ben Mabrouk et al., 2012 ) and $3.522 \times 10^{-8}$ to $1.431 \times 10^{-6} \mathrm{~m}^{2} / \mathrm{min}$, VacuumMicrowave of apple slices, respectively (Chong et al., 2013). The values for $D_{\text {eff }}$ obtained from IR drying were greater than hot-air drying. The effective moisture diffusivity was found to range between $3.499 \times 10^{-7}$ $4.746 \times 10^{-7} \mathrm{~m}^{2} / \mathrm{sec}$ and $3.671 \times 10^{-7}-5.101 \times 10^{-7} \mathrm{~m}^{2} / \mathrm{sec}$ for hot-air and IR drying, respectively.The activation energy was calculated by plotting the natural logarithm of $\mathrm{D}_{\text {eff }}$ versus reciprocal of the absolute temperature as showed in Fig. 7 and 8. The plot was found to be a straight line in the range of drying air temperature studied, indicating Arrhenius dependence. The activation energy values were found to be 140.1 and $94.62 \mathrm{~kJ} \mathrm{moL}^{-1}$ for IR and hot air drying, respectively. The dependence of the effective diffusivity of apple samples on the drying air temperature can be represented by the following equation.

IR drying Equation 11:

$$
\mathrm{D}_{\text {eff }}=9.71 \times 10^{-6} \exp \left(-1154.1 \frac{1}{\mathrm{~T}}\right) \mathrm{R}^{2}=0.91
$$

Hot-air drying Equation 12:

$$
\mathrm{D}_{\text {eff }}=3.39 \times 10^{-6} \exp \left(-758.51 \frac{1}{\mathrm{~T}}\right) \mathrm{R}^{2}=0.98
$$

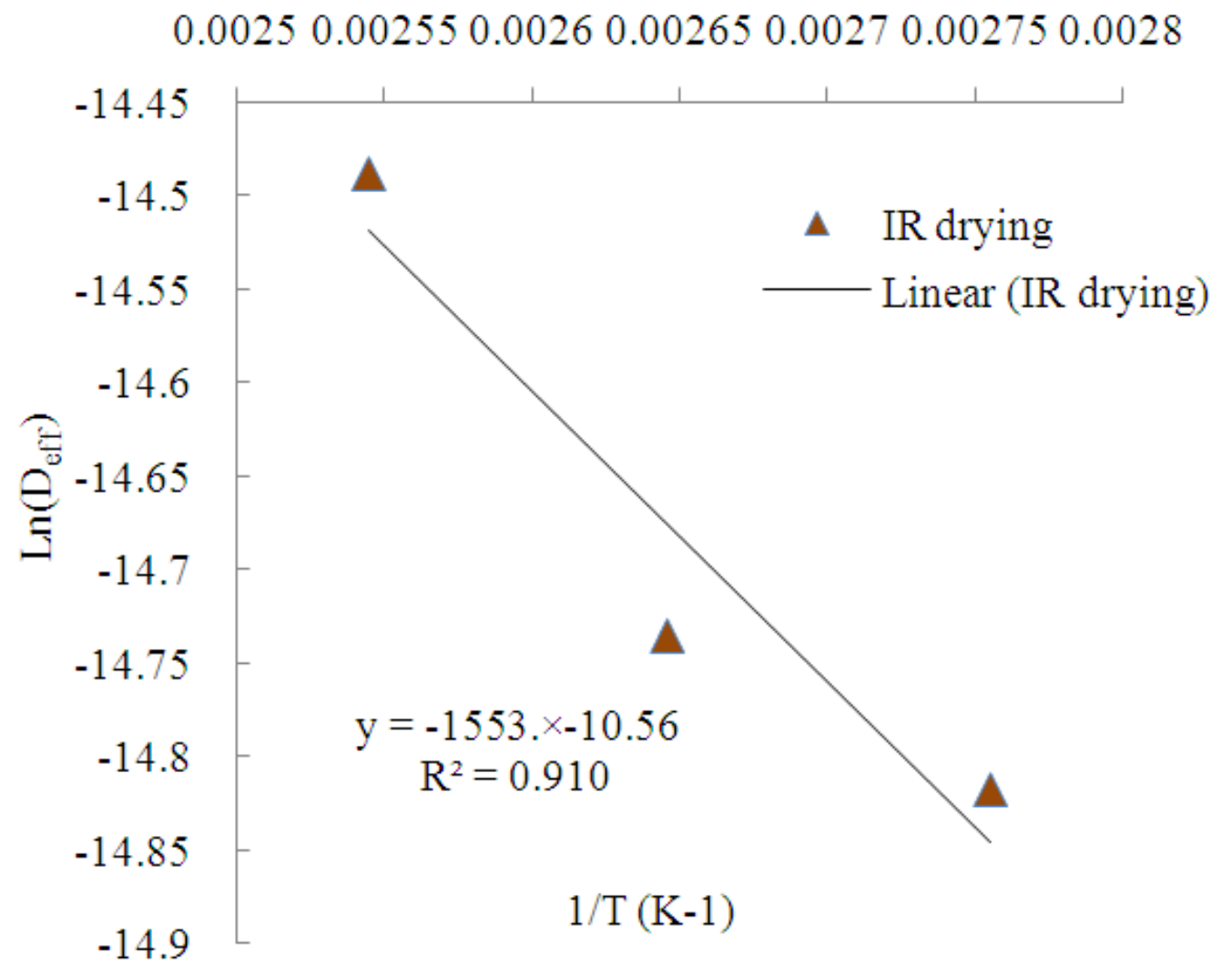

Fig. 7. Arrhenius-type relationship between effective moisture diffusivity $\left(D_{\text {eff }}\right)$ and drying air temperature for IR drying 


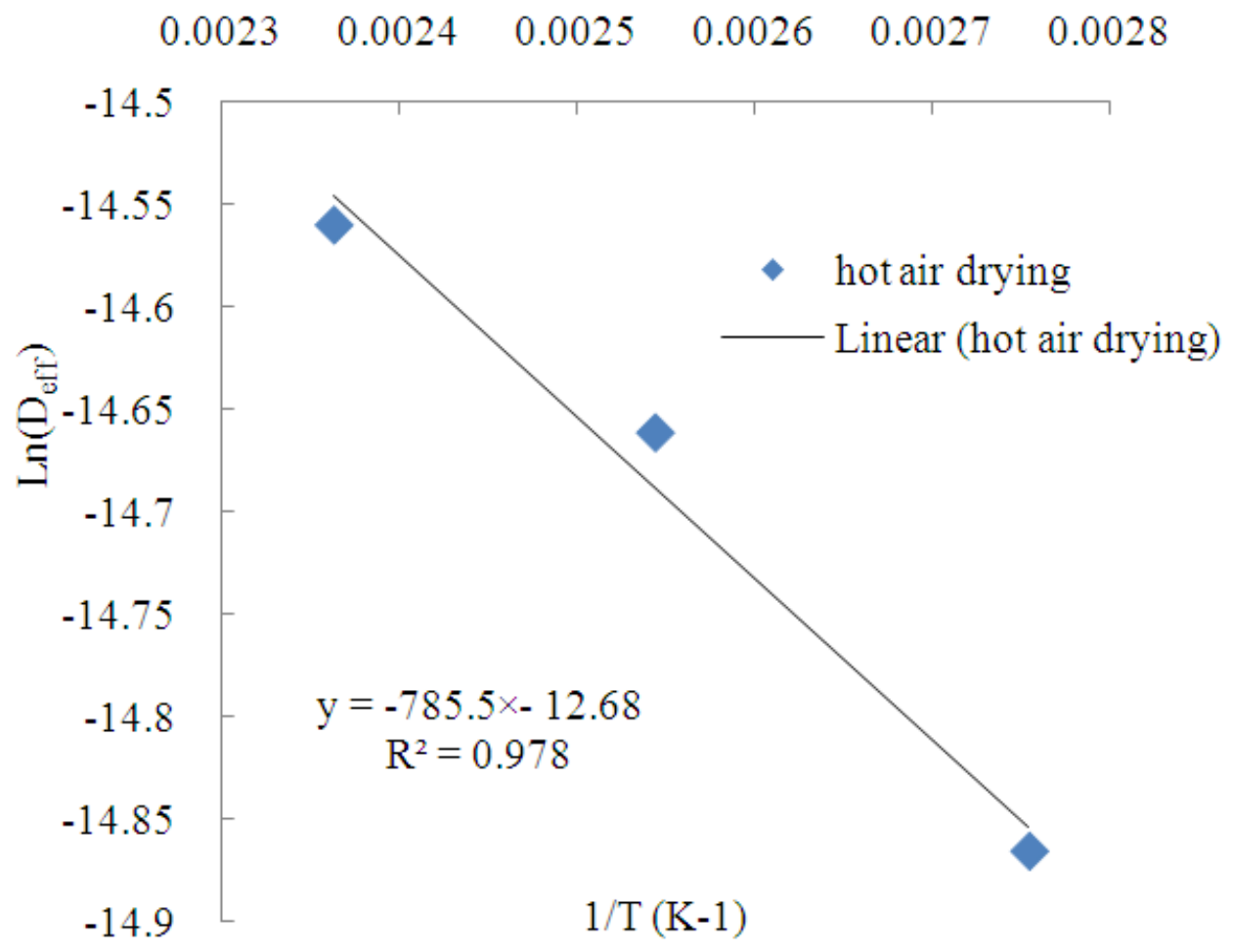

Fig. 8. Arrhenius-type relationship between effective moisture diffusivity $\left(D_{\text {eff }}\right)$ and drying air temperature for hot-air drying

Table 1. Values of effective diffusivity for hot air and IR drying at various conditions

\begin{tabular}{lll}
\hline & Air temperature $\left({ }^{\circ} \mathrm{C}\right)$ & Effective diffusivity $\times 10^{7}\left(\mathrm{~m}^{2} / \mathrm{s}\right)$ \\
\hline Hot air drying & 90 & 3.499 \\
& 120 & 4.290 \\
& 150 & 4.746 \\
Radiation intensity $\left(\mathbf{W} / \mathbf{c m}^{2}\right)$ & & \\
IR drying & 0.22 & 3.671 \\
& 0.31 & 3.985 \\
& 0.49 & 5.101 \\
\hline
\end{tabular}

\section{CONCLUSION}

In this research work, the drying behavior of apple sliced was studied under hot air and infrared drying. According to the result, drying time decreased significantly with increasing air temperature. Drying time in the Infrared dryer was lower compared to hot air dryer. Minimum energy consumed for drying apple slices in infrared dryer was $1 \mathrm{~kW} \mathrm{~h}$ at $0.49 \mathrm{~W} / \mathrm{cm}^{2}$ radiation intensity while minimum energy consumption in hot air dryer was $7.02 \mathrm{~kW} \mathrm{~h}$ at dying temperature of $150^{\circ} \mathrm{C}$. The results showed that the Specific Energy Consumption (SEC) in the Infrared dryer was lower compared to hot air dryer. The value of SEC of apple under IR and hot air drying was ranged from 110.35 to $71.78 \mathrm{kWh} / \mathrm{kg}_{\text {water }}$ and 635.53 to $501.15 \mathrm{kWh} / \mathrm{Kg}_{\text {water }}$, respectively. The values for Deff obtained from IR drying were greater than hot-air drying. The value of effective moisture diffusivity varied from $3.499 \times 10-7$ $4.746 \times 10-7 \mathrm{~m}^{2} / \mathrm{sec}$ and $3.671 \times 10-7-5.101 \times 10-7 \mathrm{~m}^{2} / \mathrm{sec}$ for hot-air and IR drying, respectively fruit in this study. Also, the activation energy values were found to be 140.1 and $94.62 \mathrm{~kJ} \mathrm{moL}^{-1}$ for IR and hot air drying, respectively. The overall conclusion of present works is thatInfrared dryer compared to hot air dryers have been better in view of aspects energy for drying apple slices. 


\section{REFERENCES}

Bakal, S.B., G.P. Sharma, S.P. Sonawan and R.C. Verma. 2011. Kinetics of potato drying using fluidized bed dryer. J. Food Sci. Technol., 49: 608613. DOI: 10.1007/s13197-011-0328-x

Balbay, A., Y. Kaya and O. Sahin. 2012. Drying of black cumin (Nigella sativa) in a microwave assisted drying system and modeling using extreme learning machine. Energ, 44: 352-357. DOI: 10.1016/j.energy.2012.06.022

Barati, E. and J.A. Esfahani, 2011. Mathematical modeling of convective drying: Lumped temperature and spatially distributed moisture in slab. Energy, 36: 2294-2301. DOI: 10.1016/j.energy.2010.06.007

Ben Mabrouk, S., E. Benali and H. Oueslati. 2012. Experimental study and numerical modelling of drying characteristics of apple slices. Food Bioprod. Process., $\quad 90$ : 719-728. DOI: 10.1016/j.fbp.2012.02.001

Celma, A.R., F.L. Rodriguez and F.C. Blazquez, 2009. Experimental modelling of infrared drying of industrial grape by-products. Food Bioprod. Process., $\quad 87$ : 247-253. DOI: 10.1016/j.fbp.2008.10.005

Chong, C.H., A. Figiel, C. Law and A. Wojdyło. 2013. Combined drying of apple cubes by using of heat pump, vacuum-microwave and intermittent techniques. Food Bioprocess Technol. DOI: 10.1007/s1 1947-013-1123-7

Darvishi, H., M. Azadbakht, A. Rezaeiasl and A. Farhang. 2013. Drying characteristics of sardine fish dried with microwave heating. J. Saudi Soc. Agric. Sci., 12: 121-127. DOI: 10.1016/j.jssas.2012.09.002

Dissa, A.O., D.J. Bathiebo, H. Desmorieux, O. Coulibaly and J. Koulidiati. 2011. Experimental characterisation and modelling of thin layer direct solar drying of Amelie and Brooks mangoes. Energ, 36: 2517-2527. DOI: 10.1016/j.energy.2011.01.044

Doymaz, I., 2010. Effect of citric acid and blanching pretreatments on drying and rehydration of Amasya red apples. Food Bioprod. Process., 88: 124-132. DOI: 10.1016/j.fbp.2009.09.003

Doymaz, I. and O. Ismail, 2011. Drying characteristics of sweet cherry. Food Bioprod. Process., 89: 31-38. DOI: $10.1016 /$ j.fbp.2010.03.006

FAOSTAT, 2012. Fao Stat Database. FAO.
Forsline, P.L., H.S. Aldwinckle, E.E. Dickson, J.J. Luby and S.C. Hokanson, 2002. Collection, Maintenance, Characterization and Utilization of Wild Apples of Central Asia. In: Horticultural Reviews, Wild Apple and Fruit Trees of Central Asia, Janick, J. (Ed.). John Wiley Sons, Hoboken, ISBN-10: 0471219681, pp: $1-405$.

Hebbar, U.H., K.H. Vishwanathan and M.N. Ramesh, 2004. Development of combined infrared and hot air dryer for vegetables. J. Food Eng., 65: 557-563. DOI: 10.1016/j.jfoodeng.2004.02.020

Jindarat, W., P. Rattanadecho and S. Vongpradubcha, 2011. Analysis of energy consumption in microwave and convective drying process of multi-layered porous material inside a rectangular wave guide. Exp. Thermal Fluid Sci., 35: 728-737. DOI: 10.1016/j.expthermflusci.2010.11.008

Kahyaoglu, L.N., S. Sahin and G. Sumnu, 2012. Spouted bed and microwave-assisted spouted bed drying of parboiled wheat. Food Bioprod. Proc., 90: 301-308. DOI: $10.1016 /$ j.fbp.2011.06.003

Kamble, A.K., S.R. Kalbande, M. Deshmukh and S.R. Gadge, 2011. Solar drying system for energy conservation. Applied Solar Energy, 47: 124-133. DOI: 10.3103/S0003701X11020101

Khir, R., Z. Pan, A. Salim, B.R. Hartsough and S. Mohamed, 2011. Moisture diffusivity of rough rice under infrared radiation drying. WT-Food Sci. Technol., 44: 1126-1132. DOI: 10.1016/j.lwt.2010.10.003

Lin, Y.P., J.H. Tsen and V. An-Erl King, 2005. Effects of far-infrared radiation on the freeze-drying of sweet potato. J. Food Eng., 68: 249-255. DOI: 10.1016/j.jfoodeng.2004.05.037

Meeso, N., A. Nathakaranakule, T. Madhiyanon and S. Soponronnarit, 2004. Influence of FIR irradiation on paddy moisture reduction and milling quality after fluidized bed drying. J. Food Eng., 65: 293-301. DOI: 10.1016/j.jfoodeng.2004.01.033

Motevali, A., S. Minaei, M.H. Khoshtaghaza, M. Kazemi and A.M. Nikbakht, 2010. Drying of pomegranate arils: Comparison of predictions from mathematical models and neural networks. Int. J. Food Eng., 6: 120. DOI: $10.2202 / 1556-3758.1889$

Motevali, A., S. Minaei and M.H. Khoshtagaza. 2011. Evaluation of energy consumption in different drying methods. Energ Convers. Manage., 52: 11921199. DOI: 10.1016/j.enconman.2010.09.014 
Nathakaranakule, A., P. Jaiboon and S. Soponronnarit, 2010. Far-infrared radiation assisted drying of longan fruit. J. Food Eng., 100: 662-668. DOI: 10.1016/j.jfoodeng.2010.05.016

Niamnuy, C., M. Nachaisin, N. Poomsa-ad and S. Devahastin, 2012. Kinetic modelling of drying and conversion/degradation of isoflavones during infrared drying of soybean. Food Chem., 133: 946952. DOI: 10.1016/j.foodchem.2012.02.010

Nimmol, C., S. Devahastin, T. Swasdisevi and S. Soponronnarit, 2007. Drying of banana slices using combined low-pressure superheated steam and farinfrared radiation. J. Food Eng. Biolog. Syst., 81: 624-633.

Nowak, D. and P.P. Lewicki, 2004. Infrared drying of apple slices. Innovative Food Sci. Emerg. Technol., 5: 353-360. DOI: 10.1016/j.ifset.2004.03.003

Pathare, P.B. and G.P. Sharma, 2006. Effective moisture diffusivity of onion slices undergoing infrared convective drying. Biosyst. Eng., 93: 285-291. DOI: 10.1016/j.biosystemseng.2005.12.010

Ponkham, K., N. Meesoa, S. Soponronnaritb and S. Siriamornpunc, 2012. Modeling of combined farinfrared radiation and air drying of a ring shapedpineapple with/without shrinkage. Food Bioprod. Process., 90: 155-164. DOI: 10.1016/j.fbp.2011.02.008

Purkayastha, M.D., A. Nath, B.C. Deka and C.L. Mahanta. 2013. Erratum to: Thin layer drying of tomato slices. J. Food Sci. Technol., 50: 654-654. DOI: $10.1007 / \mathrm{s} 13197-011-0532-8$

Samadi, S.H., B. Ghobadian, G.H. Najafi, A. Motevali and S. Faal. 2013. Drying of apple slices in Combined Heat and Power (CHP) Dryer: Comparison of mathematical models and neural networks. Chem. Product Proc Model., 8: 1-12. DOI: $10.1515 / \mathrm{cppm}-2013-0009$.

Sharma, G.P., R.C. Verma and P. Pathare, 2005. Mathematical modeling of infrared radiation thin layer drying of onion slices. J. Food Eng., 71: 282286. DOI: $10.1016 /$ j.jfoodeng.2005.02.010
Shi, J., Z. Pan, T.H. McHugh, D. Wood and E. Hirschberg et al., 2008. Drying and quality characteristics of fresh and sugar-infused blueberries dried with infrared radiation heating. LWT-Food Sci. Technol., 41: 1962-1972. DOI: 10.1016/j.lwt.2008.01.003

Shi, Q., Y. Zheng and Y. Zhao. 2013. Mathematical modeling on thin-layer heat pump drying of yacon (Smallanthus sonchifolius) slices. Energ Convers. Manage., 71: 208-216. DOI: 10.1016/j.enconman.2013.03.032

Van 't Land, C.M., 2011. Drying in the Process Industry. 1st Edn., John Wiley and Sons, Hoboken, ISBN-10: 1118105826, pp: 368.

VijayaVenkataRaman, S., S. Iniyan and R. Goic, 2012. A review of solar drying technologies. Renew. Sustainable Energy Rev., 16: 2652-2670. DOI: 10.1016/j.rser.2012.01.007

Vishwanathan, K.H., G.K. Giwari and H.U. Hebba, 2013. Infrared assisted dry-blanching and hybrid drying of carrot. Food Bioprod. Process., 91: 89-94. DOI: 10.1016/j.fbp.2012.11.004

Wang, J. and K. Sheng, 2006. Far-infrared and microwave drying of peach. LWT-Food Sci. Technol., 39: 247-255. DOI: 10.1016/j.lwt.2005.02.001

Zlatanović, I., M. Komatina and D. Antonijević. 2013. Low-temperature convective drying of apple cubes. Applied Therm. Eng., 53: 114-123. DOI: 10.1016/j.applthermaleng.2013.01.012 